\title{
多次元多変量光学計測による乱流予混合火焱の可視化*
}

\author{
店橋 護**, 志村 祐康 $* *$, 福島 直哉 $* * * *$
}

\section{Visualization of Turbulent Premixed Flames by Multi-Dimensional/Multi-Variable Laser Diagnostics}

\author{
Mamoru Tanahashi, Masayasu Shimura and Naoya Fukushima
}

\section{1.はじめに}

自動車用エンジンや発電用・航空機用ガスタービンで は，乱流燃焼によってエネルギー変換が行われている。 近年の地球環境問題を解決するには，これら燃焼器の更 なる高効率化と低環境負荷化が求められているが，これ には「乱流燃焼現象」そのものの解明が必要不可欠であ る。乱流燃焼は，幅広い時間・空間スケールを有する乱 流と幅広い時間スケールを有する複雑な化学反応から成 る燃焼が相互に干渉する複雑現象であるため，理論的な アプローチが非常に困難であるとともに，実験的にも数 值的にも取り扱いが難しい. 例えば, Fig. 1 は航空機用 ガスタービン燃焼器の $1 / 100$ 程度の出力のモデル燃焼 器に形成される乱流予混合火炎の直接写真を示している。 ここで，予混合火炎とは燃料と酸化剂を予め良く混合し ておき，その混合気を燃焼器内に噴射して燃やす燃焼形 態であり，家庭用ガスコンロや自動車用ガソリンエンジ ンに一般的に用いられている．燃焼反応では特定の化学 物質が光を発し，それらは自発光と呼ばれる。Fig. 1 に 示した画像は，この自発光を物理現象の時間スケールに 比べて長い露光時間で撮影したものであり，これは我々 が肉眼で見られるものとほぼ同等である。このように乱 流燃焼は我々の肉眼でも観察することが可能であるが, 瞬時の現象は極めて複雑であり，これを解明するには高 い時間・空間分解能での詳細な計測が必要となる。本稿 では，乱流燃焼機構を解明するために開発されてきた最 先端のレーザ計測法について解説する。

\section{2. 二平面時系列ステレオ投影粒子画像流速計}

前述のように，乱流燃焼は乱流と燃焼反応という二つ の複雑現象から構成されている。このため，まず流体運 動の正確な計測が必要である。流体速度の計測には，流

* 原稿受付 2010 年 10 月 28 日

** 東京工業大学大学院 理工学研究科 (T 152-8550 東京都 目黒区大岡山 2-12-1, E-mail：mtanahas@ mes.titech.ac jp)

*** 東京工業大学大学院 理工学研究科

**** 東京工業大学大学院 理工学研究科
体中に混入した微小粒子にシート状のレーザ光を照射し， 微小時間異なる粒子画像から流体速度を算出する粒子画 像流速計（PIV）が一般的に用いられている。近年では, 比較的高い時間分解能の時系列 PIV（あるいは夕゙イナ ミックPIV）が一般的になりつつある。気体の高速な 流動を伴う乱流燃焼では，その動的特性を明らかにする には数 $10 \mathrm{kHz}$ 以上の時間分解能を有する時系列 PIV が必要となる。そのような時系列 PIVの開発について は，以前に本誌1などにおいて紹介したので，ここでは 最新の計測技術についてのみ紹介することとする.

最も基本的な PIV では，二次元平面の粒子画像から その平面内の粒子パ夕ーンの移動を求め, 計測平面内の 流体速度 2 成分の二次元分布が計測できる。粒子画像を 異なる角度から二台のカメラで撮影し，それらから 3 成 分目の速度を得るのがステレオ投影 PIVであり，二次 元平面内の流体速度 3 成分が計測可能である。乱流現象 は本質的に三次元であるとともに，乱流中の渦や歪みな ど秩序構造を議論するためには速度の勾配に関する情報 も必要であるので，計測平面を二平面に拡張した二平面 ステレオ PIV や三次元空間の速度 3 成分が得られるホ ログラフィック PIV 等も開発されている。ここで，最 新の二平面ステレオ PIV について紹介する，後ほど説 明するが，二平面ステレオ PIVでは，流体速度 3 成分 とその全方向の速度勾配（9 成分）の面情報を与える。 乱流火炎の局所構造を議論する上で，速度勾配に関する 情報は非常に重要である。

二平面ステレオ PIVでは, 微小距離異なる位置に平

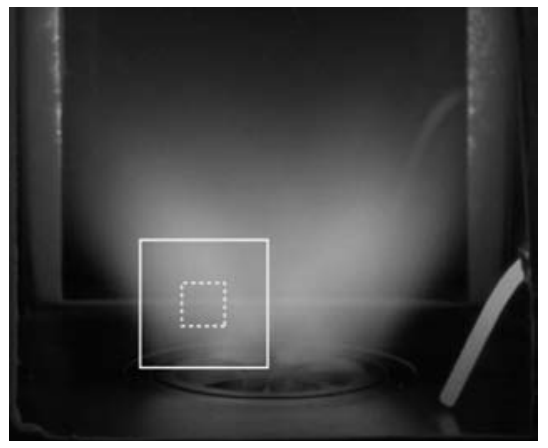

Fig. 1 Direct photograph of turbulent methane-air premixed flame in a gas turbine model combustor. 


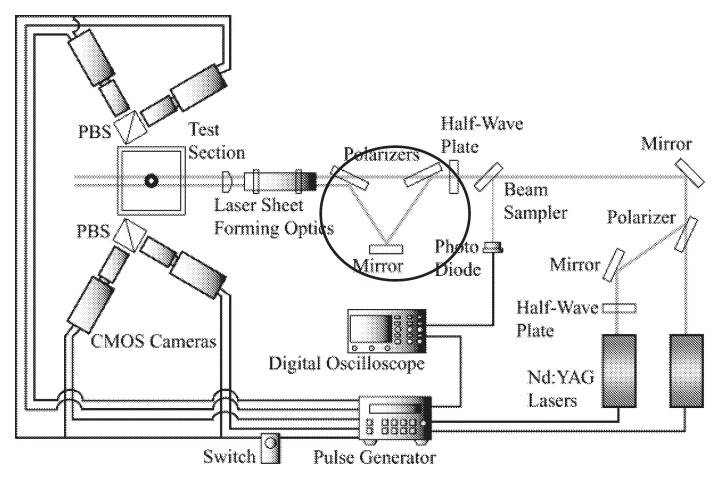

Fig. 2 Schematic of polarization-based dual-plane stereoscopic PIV system.

行なレーザシートを照射し，それぞれの面の粒子画像を それぞれ 2 台ずつ，合計 4 台のカメラで撮影し，二平面 上での流体速度 3 成分を計測する。二平面の粒子画像を 撮り分けるには, レーザ光の偏光の違いを利用する偏光 型とレーザ光の波長の違いを利用する波長型がある。偏 光型の場合, 通常, 二平面ステレオ PIV システムを構 成するには，単一平面のステレオ PIV に，カメラ 2 台， シングルパルスレーザ 2 台（あるいは，无ブルパルス レーザ 1 台）を追加する必要があり，計測システムは非 常に高額となる。付加コストを低減するために開発され た特殊光学系を用いた偏光型二平面時系列ステレオ PIV システムの例2) Fig. 2 に示す.このシステムでは,

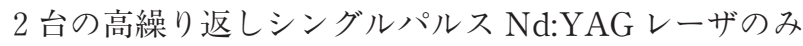
を用いて二平面時系列ステレオ PIVが実現されており, 最高で $26.7 \mathrm{kHz}$ での速度計測が可能となる。キーとな る装置は, Fig. 2 中の○で示した平行ビーム生成光学系 であり, この光学系を用いることで, 通常の単一平面ス テレオ PIV システムにカメラ 2 台を追加するだけで二 平面ステレオ PIVに拡張できる。実際に通常のダブル パルス Nd:YAGレーザ 1 台と $2048 \times 2048$ ピクセルの 高解像度 CCD カメラ 4 台を用いて計測された結果3)を Fig. 3 に示す。ここでベクトルは速度を, 各平面内の色 は流体の回転量とその回転方向を表す渦度を示している. 二平面間の距離は, $560 \mu \mathrm{m}$ であり, 見やすくするため に実際のスケール比の 15 倍で描かれている. 乱流現象 を解明するために，直接数值計算 (DNS) と呼ばれる 高精度な数值計算が行われているが，この計測はDNS とほぼ同等な空間分解能（通常 DNS では乱流運動の最 小スケール，すなわちコルモゴロフスケールの約 3 倍以 下の格子分解能が用いられる）である. Fig. 3 に示した ように乱流運動に含まれる微細な渦運動を良く捉えてお り，すべての速度勾配について DNS 結果などと非常に 良く一致する4).

乱流燃焼の場合, 流体運動による歪みが局所的な火炎 の挙動に大きな影響を与えると考えられている。このた め，上述のような流体速度のみならず，速度勾配に関す る詳細な情報を与える二平面ステレオ PIV は非常に有 効であり，その応用例については第 4 章で紹介する.

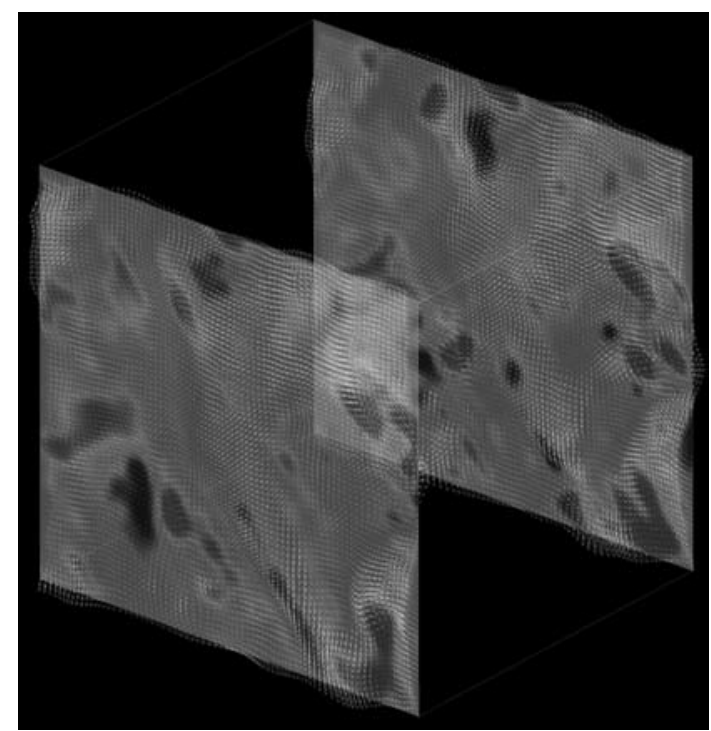

Fig. 3 Typical velocity and vorticity distributions obtained by high spatial resolution polarizationbased dual-plane stereoscopic PIV.

\section{3. 多化学種同時平面レーザ誘起蛍光法}

燃焼側の計測には，平面レーザ誘起蛍光法（PLIF） が頻繁に用いられている。 Fig. 1 に示した自発光は，火 炎全体から発せられる光の光路積分として画像化される ため，局所的な火炎の構造を議論するには必ずしも適切 ではない.PLIFではシート状のレーザ光で分子を励起 し，その後の電子準位の変化に応じて発せられる蛍光を 高感度カメラ（通常はイメージインテンシファイア付き CCD（ICCD） カメラ）で撮影する。レーザ光が照射さ れた平面内の情報のみが画像化されるため，自発光とは 異なり詳細な火炎情報を与える。燃焼場では燃焼反応に 関与する $\mathrm{OH}, \mathrm{CH}, \mathrm{CH}_{2} \mathrm{O}$ 等の中間生成物（ラジカル） を計測対象とする場合が多い。最も一般的な対象は $\mathrm{OH}$ であり，OH ラジカルは燃焼反応が終了もしくは終了段 階にある部分で高い濃度を示すため，未燃領域と既燃領 域を分離するには非常に便利である．CH ラジカルは， 燃焼反応により結合エネルギーが熱エネルギーに急激に 変換される熱発生領域で高い濃度を示すため，炇面を 特定するために頻繁に用いられている。ただし，CH ラ ジカルの濃度は，OH ラジカルに比べて低いため, PLIF 計測も容易ではない.

\subsection{OH-CH PLIF とステレオPIV の同時計測}

実用燃焼器で用いられている乱流燃焼場は, 極めて乱 れた高レイノルズ数の条件にあり, $\mathrm{OH}$ ラジカルや $\mathrm{CH}$ ラジカルなど, 単独の化学種を対象としたPLIF 計測で は, 必ずしも十分な情報を与えない. そこで, 複数の化 学種の同時 PLIF 計測が行われている. Fig. 4 は, $\mathrm{OH}$ ラジカルと $\mathrm{CH}$ ラジカルの同時 PLIF にステレオ PIV を組み合わせた 2 化学種濃度及び流体速度 3 成分の同時 計測システムの一例を示している4).この例では, それ ぞれの化学種に対応した波長の励起光を発振するために, 


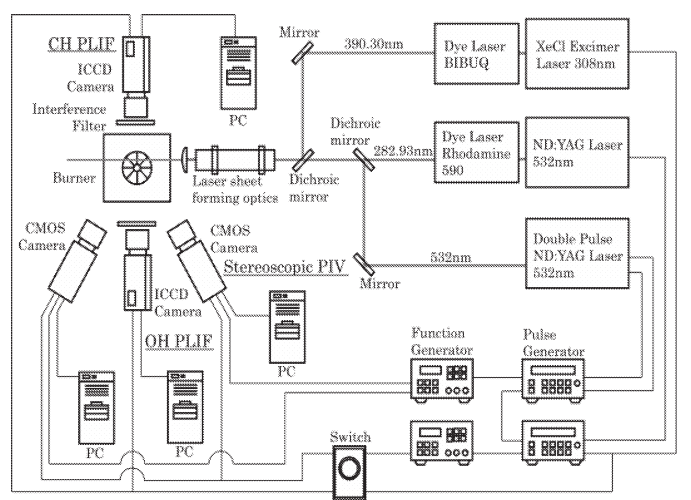

Fig. 4 Schematic of simultaneous OH-CH PLIF and stereoscopic PIV system

$\mathrm{Nd}$ ：YAGレーザあるいはエキシマレーザと色素レー ザから成る二組の PLIF 計測システムが用いられている. 波長の異なる励起光はダイクロイックミラーと呼ばれる 特殊なミラーを用いて一つの光軸上に導かれ，シート状 のレーザ光に変換する光学系を介して, 燃焼器内の同一 の二次元断面に照射される。ラジカルに依って蛍光の波 長も異なるため, 燃焼器の両側に配置された ICCD 力 メラと特定の波長の光を透過される光学フィルターを組 み合わせることで二つのラジカルからの蛍光を分離して 画像化する。ここで，ICCD カメラのゲート時間（露光 時間）は $30 \mathrm{~ns}$ であり，蛍光以外の光の混入を最小限に 止めている。

流体速度の計測には，比較的発振周波数が低いダブル パルス Nd:YAG レーザが用いられているが，粒子画像 の取得には高速 CMOSカメラ 2 台が用いられている.

ここで, 高速 CMOSカメラは, $3 \mathrm{kHz}$ 程度の高速で稼 働されているが，実際に画像が取得されるのは数千画像 のうちの 2 画像のみである。これは，火炎からの自発光 が粒子画像に写り込むことを防止するための方策である。

Fig. 1 に示した乱流予混合火炎において $\mathrm{OH}-\mathrm{CH}$ PLIF とステレオ PIV で同時計測した一例を Fig.5 に示 す. 計測領域は Fig. 1 に示した白枠の領域であり, Fig. 5 の $\mathrm{CH}$ ラジカルと $\mathrm{OH}$ ラジカルの蛍光イメージ中の 白枠がステレオ PIVの計測領域に対応している。流体 速度の計測結果はべクトルが計測面内の速度成分を色が 面外方向の速度成分の大きさを示している. Fig. 1 の直 接写真や我々の肉眼での観察とは異なり, 乱流予混合火 炎は火炎及び流体速度の極めて高速な変動を含んでおり, それらはこのような詳細な計測を通してのみ解析するこ とができる。また， $\mathrm{OH}$ ラジカルと $\mathrm{CH}$ ラジカルを同時 に計測することで，未燃領域と既燃領域の分離及び火炎 面の位置が明確となり，極めて複雑な形状を有する火炎 面の局所的な特性を議論することができる。例えば,

Fig. 6 に示すように, CH ラジカルの蛍光イメージから 火炎位置を特定し, $\mathrm{OH}$ ラジカルの蛍光イメージから火 炎面の法線方向を特定することが可能である。一般に, 極めて複雑な乱流中の火炎面であっても，その動的特性
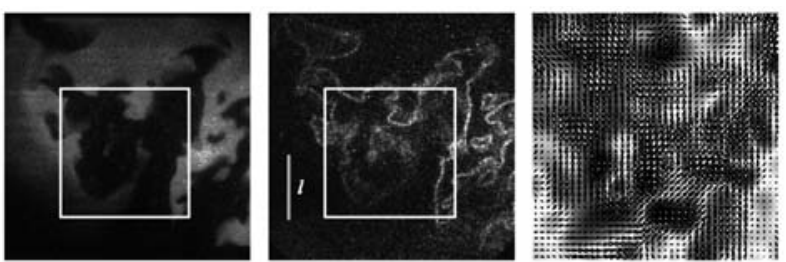

Fig. 5 A typical result of simultaneous OH-CH PLIF and stereoscopic PIV
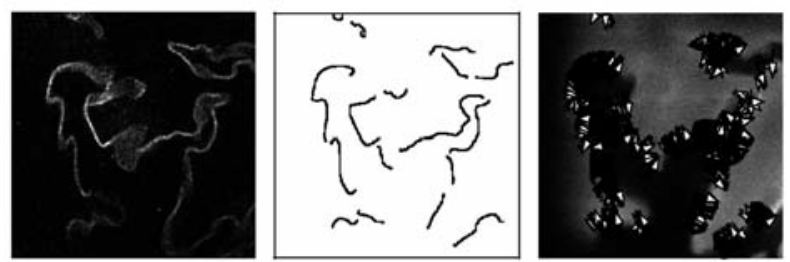

Fig. 6 Identification of flame fronts and flame-normal unit vectors from simultaneous OH-CH PLIF.

は火炎面の局所的な曲率と流体運動により火炎面の接線 方向に作用する歪み速度（流体の速度勾配から算出され る）から記述できると予測されており，実験的にそのよ うな理論の検証やモデルの構築を行うために重要となる.

\section{2 ダブルパルス CH PLIF 計測}

前節で示したように，乱流火炎の平均的な特性（直接 写真や肉眼で観察できる特性）と瞬間的な火炎の構造は 大きく異なる，非常に高速で変動する乱流火炎の動的特 性の解明は，乱流燃焼機構の解明とその高精度モデルの 構築には必要不可欠である。前節，Fig. 4 に示した計測 システムを応用することで，乱流中での火炎面の非定常 特性を検討することができる。すなわち, $\mathrm{OH}$ ラジカル の励起用に用いられている PLIF システムの色素レーザ の色素を $\mathrm{CH}$ ラジカルの励起波長 $(390.30 \mathrm{~nm})$ の光を 発振するものに変更し，ダイクロイックミラーの代わり に，390.30 nmの光に対応した偏光ビームスプリッター を用いる。こうすることで，偏光を利用して同一波長 $(390.30 \mathrm{~nm})$ の光を一光軸上に導くことが可能となる. ICCD カメラの撮像は高精度に制御することが可能であ るため, 微小時間異なる夕イミングで $\mathrm{CH}$ ラジカルの PLIF 計測（ダブルパルス CH PLIF 計測）が可能とな る.Fig. 7 は，ダブルパルス CH PLIF 計測の一例を示 している5)。計測は，前節までと同様にガスタービンを 模擬したモデル燃焼器において行われており，時間間隔 を $200 \mu \mathrm{s}$ とした計測から得られた典型的な結果を示し ている。このような計測から，既燃ガス中に孤立した未 燃ガスが急速に燃焼する様子や比較的大きな未燃ガスの 塊が主要な火炎面から分離する様子（Fig.7 中の B 領 域）が明らかにされている。このダブルパルス $\mathrm{CH}$ PLIF を用いることで，乱流中の火炎面の大域的なダイ ナミクスを検討することができる。ただし，この計測は 単一平面において行われているため，三次元的に炎面 が本当に分離しているかどうかは，次節で紹介する多平 面 PLIF などを用いない限り定かではない。 


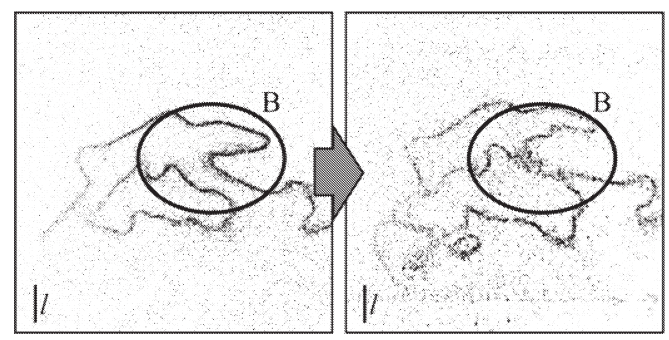

Fig. 7 Flame dynamics obtained from double-pulsed $\mathrm{CH}$ PLIF.

多くの実用的な燃焼器において乱流燃焼が用いられる 最大の理由は, そのエネルギー密度の高さにある. 乱流 火炎の最も基本的な概念モデルでは，複雑な形状を示す 火炎面であっても局所的には層流火炎と近似可能であり, 複雑に折り畳まれることで面積が増加し，その面積増加 によりトータルの燃料消費量が増加すると考える。局所 的な炏炎要素を層流火炎とするモデルは炏炎片 (Flamelet) モデルと呼ばれている。このような考え方 は，乱流と火炎面（燃焼反応）との時間スケールの差が 極めて大きい場合には正しいものとなるが，実際の燃焼 器ではこの差はそれほど大きくなく, 強い乱流と火炎面 の干渉が生じているものと考えられている。上述のダブ ルパルス CH PLIF の時間間隔をさらに小さくすると, 局所的な火炎要素のダイナミクスを検討することが可能 となる.Fig. 8 は時間間隔を $30 \mu \mathrm{s}$ とした場合の連続す る CH PLIFイメージを示している。ここで, 赤は第一 イメージ，青は $30 \mu \mathrm{s}$ 後の第二イメージである。ここで, 局所的な火炎要素を同定し，PIVにおいて流体速度の 算出に用いられている相互相関法を応用することで，局 所火炎要素の移動速度を求名ことができる. Fig.8 中 の白色べクトルは，局所火炎要素の移動方向とその速さ を示している。この計測法をさらに拡張すると，層流火 炎片モデル等を実験的に直接検証することができる。こ れについては次章で簡単に紹介する。

近年では， 4 台の Nd:YAGレーザを用いて 1 台の色 素レーザを励起する方法 ${ }^{6}$ や高繰り返しレーザを光源と して特殊な色素レーザ7)や特殊な光学系を用いる時系列 PLIF 計測 ${ }^{8)}$ が提案されている. しかし, 時系列 PLIF の時間分解能は $10 \mathrm{kHz}$ 程度である. 乱流火炎の動的特 性を検討するには本来 $20 \mathrm{kHz}$ 以上の時間分解能（50 $\mu \mathrm{s}$ 以下）が必要と考えられるが, 励起レーザの発振周 波数, 色素レーザの入力限界, 励起レーザ強度などの限 界から実現されていない。

\section{3 多平面 PLIF 計測}

乱流火炎の動的特性を記述するには，三次元的に変動 する火炎面の三次元構造を明らかにする必要がある。予 混合火炎の場合，火炎は自ら燃え広がる特性（伝播特 性）を有しており，層流中での伝播速度を層流燃焼速度 という。仮に，火炎面が湾曲してある曲率を有した場合， 火炎面面積の増加率は曲率に依存することになる。すな わち，伝播方向に凸の曲率を有していれば，火炎面面積

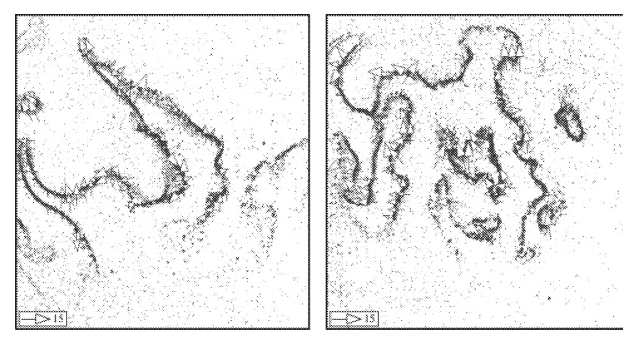

Fig. 8 Local flame displacement speed obtained from double-pulsed CH PLIF.

は増加し，伝播方向に凹の曲率を有していれば減少する。 前節までの二次元平面内の PLIF 計測では, 三次元曲面 の曲率を計測することは不可能である。前節までの PLIF 同時計測をさらに拡張すると, 乱流中の火炎面の 三次元構造を検討することができる．Fig. 9 は，二平面 CH PLIF，単一平面 OH PLIF 及び単一平面ステレオ PIV の同時計測システムの一例である ${ }^{9)}$. この計測では, 前節までの計測システムにもう一組の PLIF システムを 組み合わせ，それぞれPLIF の計測面を面外方向に微小 距離異なる位置に設定することで三平面における PLIF 計測を実現している，OH PLIFの計測面を挟む二平面 でCH PLIF 計測が行われる。異なる二平面における $\mathrm{CH}$ ラジカルの蛍光イメージは，前節と同様に対向に配 置された二台の ICCD カメラによって撮影されるが, 同時に同じ波長の蛍光を撮り分けることは不可能である ので，二平面の CH PLIFに50 ns の時間差を与えてい る。乱流火炎の時間スケールを考慮に入れれば，この時 間差は同時と考えて良い. $\mathrm{OH}$ PLIFは最初の $\mathrm{CH}$ PLIFよりも $25 \mathrm{~ns}$ 後に行われている。 OH ラジカルか らの蛍光は, 一方の CH ラジカル用 ICCD カメの前 に配置されたダイクロイックミラーにより分離され，三 台目の ICCD カメラにより撮影される.

乱流噴流予混合火炎における代表的な計測結果を Fig.10に示す。罒中の白と青はそれぞれの平面での CH ラジカルの蛍光イメージを, 黄色は $\mathrm{OH}$ ラジカルの PLIF から得られた未燃がス領域を示している。この計 測例では，既燃ガスが未燃予混合気に取り込まれる様子 （Fig.10 (a)）や未燃がスが下流方向に分離して火炎面が

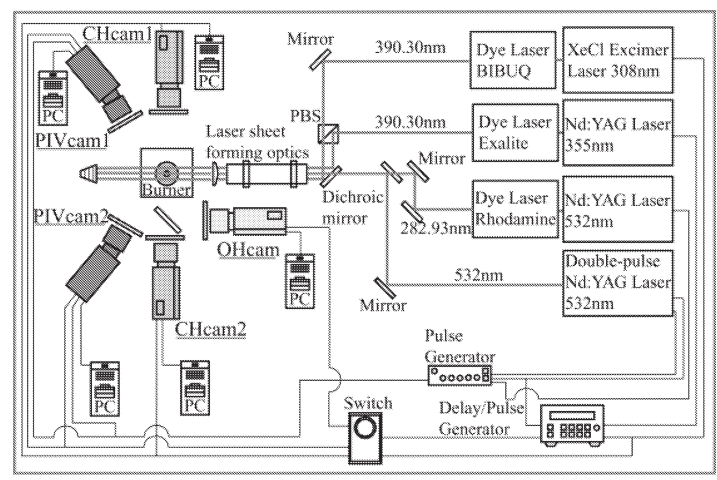

Fig. 9 Schematic of simultaneous dual-plane CH PLIF, single-plane OH PLIF and single-plane stereoscopic PIV system. 

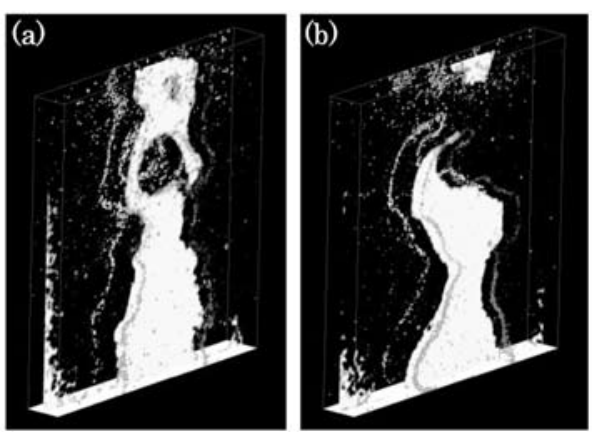

Fig.10 Typical three-dimensional flame structures obtained from simultaneous dual-plane CH PLIF and singleplane OH PLIF.

分断される様子 (Fig.10 (b)) などが可視化されている. このような計測結果を用いれば，三次元的な火炎面の曲 率をより正確に求めることが可能であり, 乱流中での局 所的な火炎構造を検討可能である。ここでは紙面の制約 から詳細は省略する。

\section{4. 乱流予混合火炎の多次元多变量光学計測}

前章までは，乱流火炎を計測するために必要となる流 体速度の計測法と火炎の計測法についてそれぞれ独立に 紹介した。これまでも述べてきたように，乱流運動と火 炎構造を同時に計測することで乱流燃焼の詳細が議論可 能となる。本章ではPLIF と PIVを組み合わせた最先 端の多次元多变量光学計測について紹介する。

4.1 ダブルパルス CH PLIF, シングルパルス OH

PLIF 及び単一平面ステレオPIV の同時計測

Fig. 9 に示した三平面 PLIF 計測を同一平面上で時間 差を付けて行えば，ダブルパルス CH PLIF とシングル パルス OH PLIF の同時計測が実現される。これにステ レオ PIV を組み合わせると, 火炎面の移動速度と火炎 面における流体速度が同時に計測可能である。二次元断 面内との制約条件があるが，これらの差を取ることで乱 流中での局所火炎要素の燃焼速度を直接計測することが 可能となる。Fig.11は乱流噴流予混合火炎で得られた 結果の一例10)を示している。困中の赤と青の線は連続す る $\mathrm{CH}$ ラジカルの蛍光強度分布を, 黒色ベクトルは流 体速度の計測面内成分の変動べクトルを, 色は流体速度 の面外成分の大きさを示している．白色ベクトルは計測 結果から火炎片モデルが正しいと仮定して算出した局所 燃焼速度を示している。このようにして得られた局所燃 焼速度の最頻值は層流燃焼速度と一致するが，その分散 は大きく，非現実的な負の局所燃焼速度を与える場合も ある。その原因としては二次元平面に計測が限定されて いることも考えられるが, DNS 結果との比較から火炎 片モデルに非定常性を考慮に入れる必要があることなど が示唆されている。

\section{2 二平面 CH PLIF, 単一平面 OH PLIF 及び二平面 \\ ステレオPIV の同時計測}

これまで紹介してきた乱流火炎におけるPLIFと

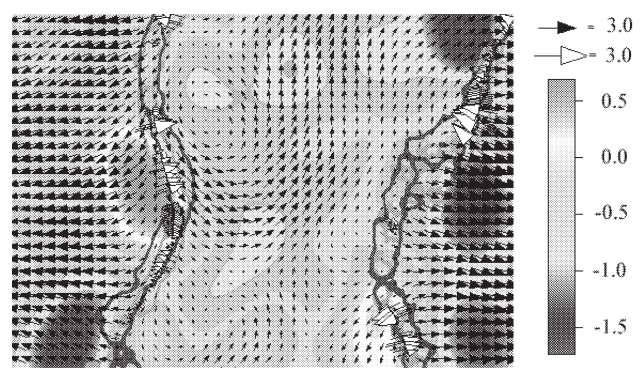

Fig. 11 A typical result of simultaneous double-pulsed $\mathrm{CH}$ PLIF, OH PLIF and single-plane stereoscopic PIV.

$\mathrm{PIV}$ の同時計測では, 流体速度の計測は単一平面に限 られている。第 2 章と第 3 章において一部触れたように, 乱流火炎の局所火炎構造の動的特性を議論するには，火 炎面近傍の流体速度により炎面の接線方向に作用する 歪み速度に関する情報が必要である。局所的な火炎面が 接線方向に伸張を受けると, 火炎面面積が増加し, それ は燃焼速度の増加につながる. 敢えて数式は使用しない が, 火炎面面積の増加率は, 曲率と接線方向の歪み速度 の関数として記述できるのである。曲率を正確に計測す るには，3.3 節で示した多平面 PLIF 計測が必要であり, 歪み速度を正確に計測するには，第 2 章で示した二平面 ステレオ PIVが必要である。これらを組み合わせた同 時計測システムの例11)を Fig.12に示す。この計測シス テムでは，波長型二平面ステレオ PIVが採用されてい る。燃焼反応を伴わない気体の場合, 微小液滴をトレー サー粒子として用いることが可能であり, 液滴はほぼ球 形であるので散乱光であっても偏光が保存され，偏光の 違いで二平面の粒子画像を取り分けることが可能である. しかし, 燃焼場において液滴粒子を用いると火炎面を通 過した液滴は高温の既然ガスにより蒸発してしまうため, 既燃ガスの流速は計測不能となる。このため燃焼場の PIV では固体粒子が用いられるのが一般的であり, こ の場合入射光の偏光は保存されない. 従って, 計測シス テムは大がかりとなるが, 波長型の二平面 PIVを用い る他はない. Fig.12の例では, 高出力 Nd:YAG レーザ 2 台からの $532 \mathrm{~nm}$ のレーザ光をそれぞれ偏光ビームス プリッターにより分離し，一部を色素レーザに入射して $560 \mathrm{~nm}$ のレーザ光に変換している. $532 \mathrm{~nm}$ と $560 \mathrm{~nm}$

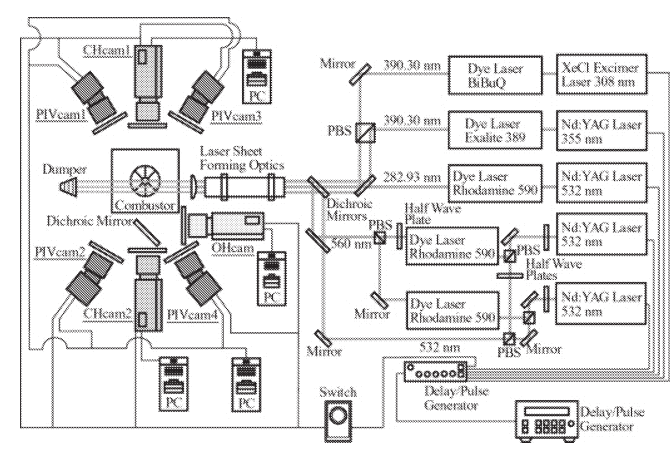

Fig. 12 Schematic of simultaneous dual-plane CH PLIF, single-plane OH PLIF and color-based dual-plane stereoscopic PIV system. 
のレーザ光は種々の光学素子を駆使して二平面上に導い ている。また, PIV 用のカメラも前出の例とは変更さ れており, 自発光の混入を防ぐための高速液晶シャッ ターを装備した $2048 \times 2048$ ピクセルの CCD メラ 4 台が用いられている。Fig.13は，この計測システムを Fig. 1 のモデル燃焼器に適用した場合に得られた三次元 火炎構造を示している. Fig.10に示した乱流噴流予混 合火炎に比べて極めて複雑な火炎面が形成されているこ とがわかる.Fig.13 中の中心付近に示した正方領域の 二平面ステレオ PIV 結果から算出した歪み速度の分布 をFig.14に示す。図中の濃淡は, $\mathrm{OH}$ ラジカルの蛍光 分布を示している。通常の一平面ステレオ PIV から見 積もられる歪み速度に比べて，その分布も大きさも異な り，二平面ステレオ PIV 計測の必要性が明らかにされ ている.

\section{5.まとめ}

本稿では, 乱流火炎の詳細な構造を計測するために開 発されてきた多次元多変量光学計測技術について紹介し た.このような計測の最終的な理想型は, 異なる二平面 で $\mathrm{CH}$ と $\mathrm{CH}_{2} \mathrm{O}$ のダブルパルスPLIFを，それに挟ま れた平面において OH のダブルパルス PLIFを行い,

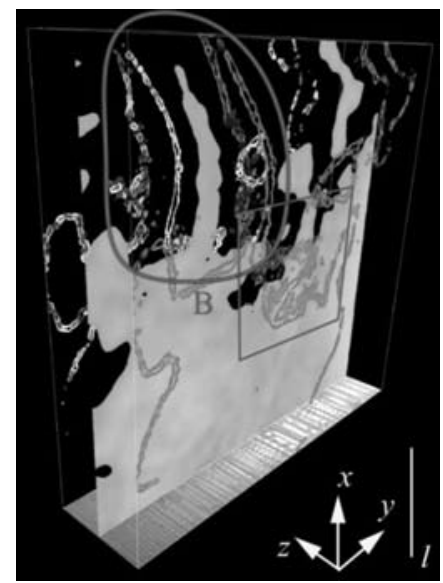

Fig.13 Typical three-dimensional flame fronts obtained by simultaneous dual-plane $\mathrm{CH}$ PLIF, single-plane $\mathrm{OH}$ PLIF and color-based dual-plane stereoscopic PIV.

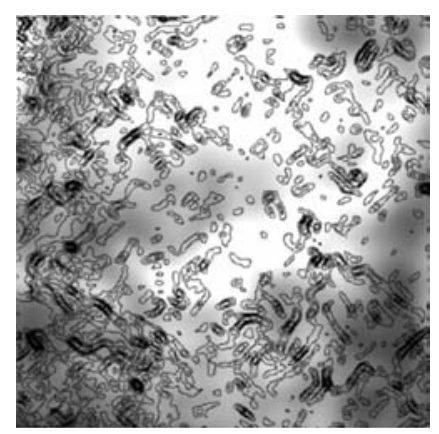

Fig.14 Distribution of strain rate obtained by simultaneous dual-plane CH PLIF, single-plane OH PLIF and color- based dual-plane stereoscopic PIV.
これに波長型二平面ステレオ PIV を組み合わせたもの である。計測には, カメラ 10 台, 励起用レーザ 8 台及 び色素レーザ 8 台が必要となる。これにより必炎面の曲 率，火炎面に作用する歪み速度及び局所燃焼速度の同時 計測が可能であるが，地震の多い我が国において，この ような計測が実現できるかどうかは定かではない.

\section{謝辞}

本稿の一部は, 科学研究費補助金若手研究(S)（No. 20676004）により行われた。ここに記して謝意を表す。

\section{参考文献}

1 ）店橋護, 崔敬民, 板倉正幸, 宮内敏雄: 時系列ステレオ PIV による乱流計測, 可視化情報, Vol.25, No.96 (2005) pp.8-13.

2 ) Tanahashi, M., Hirayama, T., Taka, S., Miyauchi, T. : Measurement of fine scale structure in turbulence by timeresolved dual-plane stereoscopic PIV, Int. J. Heat Fluid Flow, Vol.29 (2008) pp.792-802.

3 ) Tanahashi, M., Hirayama, T., Shimura, M., Ueda, T., Miyauchi, T. : Direct measurement of coherent fine scale structure in turbulence by high spatial resolution dualplane SPIV, Int. Symp. Turbulence, Heat and Mass Transfer (2009) CD-ROM.

4 ) Tanahashi, M., Murakami, S., Choi, G.-M., Fukuchi, Y., Miyauchi, T. : Simultaneous CH-OH PLIF and stereoscopic PIV measurements of turbulent premixed flames, Proc. Combust. Inst., Vol.30 (2005) pp.1665-1672.

5 ) Tanahashi, M., Taka, S., Shimura, M., Miyauchi, T. : CH double-pulsed PLIF measurement in turbulent premixed flame, Exp. Fluids, Vol. 45 (2008) pp.323-332.

6 ) Hulta, J., Meier, U., Meier, W., Harvey, A., Kaminski, C. F. : Experimental analysis of local flame extinction in a turbulent jet diffusion flame by high repetition 2-D laser techniques and multi-scalar measurements, Proc. Combust. Inst., Vol.30 (2005) pp.701-709.

7 ) Kittler, C., Dreizler, A. : Cinematographic imaging of hydroxyl radicals in turbulent flames by planar laserinduced fluorescence up to $5 \mathrm{kHz}$ repetition rate, Applied Phys. B, Vol.89 (2007) pp.163-166.

8 ) Jiang, N., Patton, R. A., Lempert, W. R., Sutton, J. A. : Development of high-repetition rate $\mathrm{CH}$ PLIF imaging in turbulent nonpremixed flames, Proc. Combust. Inst., Vol.33, in press.

9 ) Ueda, T., Shimura, M., Tanahashi, M., Miyauchi, T., : Measurement of three-dimensional flame structure by combined laser diagnostics, J. Mech. Sci. Tech., Vol.23 (2009) pp.1813-1820.

10) Tanahashi, M., Taka, S., Hirayama, T., Minamoto, Y., Miyauchi, T. : Local burning velocity measurements in turbulent jet premixed flame by simultaneous $\mathrm{CH}$ DPPLIF/OH PLIF and stereoscopic PIV, Proc. 14 th Int. Symp. Appli. Laser Tech. Fluid Mech., (2008) CD-ROM.

11) Shimura, M., Ueda, T., Choi, G.-M., Tanahashi, M., Miyauchi, T. : Simultaneous dual-plane CH PLIF, single-plane $\mathrm{OH}$ PLIF and dual-plane stereoscopic PIV measurements in methane-air turbulent premixed flames, Proc. Combust. Inst. Vol.33, in press. 